\title{
Pendapatan Asli Daerah, Pendapatan Transfer, Penerimaan Pembiayaan Dan Realisasi Belanja Modal Provinsi Bengkulu
}

Diana Endah Rahmadewi ${ }^{1}$

${ }^{1}$ Universitas Pancasila, Jl. Srengseng Sawah, Jagakarsa, Jakarta Selatan, 12640

INFO ARTIKEL

JEL Classsification:

M41

M42

Keywords:

capital expenditure,

regionally original

income, the general

allocation fund, special

allocation fund,

revenue fund, other

income.

\section{ABSTRACT}

Capital expenditure is very important role in the region, with capital expenditures, the region will be grow and capable increase investment. The purpose of this study to prove that the Regionally Original Income, Funds Transfer consisting of General Allocation Fund, Special Allocation Fund and Revenue fund, Other Income, Receipt Financing influence simultaneously and partially on capital expenditures. The sample used is the Government /City District in Bengkulu of 60 District / City from 2008-2013. The analysis tool to test the hypothesis is multiple linear regression. The results showed that in partial regionally original Income, special allocation fund, other income and receipt financing are positive effect on capital expenditures, variable general allocation fund negative effect on capital expenditures, variable revenue fund no effect on capital expenditures. Simultaneously regionally original Income, general allocation fund, special allocation fund, revenue fund, Other Income and Receipt Financing positive significant effect on capital expenditures.

\begin{abstract}
ABSTRAK
Peran Belanja Modal sangat penting di daerah, dengan belanja modal mampu membuat daerah menjadi berkembang sehingga diharapkan mampu meningkat pertumbuhan investasi di daerah tersebut. Tujuan penelitian ini untuk membuktikan bahwa Pendapatan Asli Daerah, Dana Transfer yang terdiri dari Dana Alokasi Umum, Dana Alokasi Khusus dan Dana Bagi Hasil, Pendapatan Lain Lain yang sah, Penerimaan Pembiayaan berpengaruh secara simultan dan parsial terhadap realisasi belanja modal. Sampel yang digunakan adalah 60 Kabupaten /Kota di Bengkulu dari tahun 2008-2013. Alat analisis untuk menguji hipotesis adalah regresi linier. Hasil penelitian menunjukkan bahwa secara parsial variabel Pendapatan Asli Daerah, Dana Alokasi Khusus, pendapatan lain lain yang sah, penerimaan pembiayaan berpengaruh positif terhadap realisasi belanja modal, variabel Dana Alokasi Umum berpengaruh negative terhadap realisasi belanja modal, variabel Dana Bagi Hasil tidak berpengaruh terhadap realisasi belanja modal. Secara simultan Pendapatan Asli Daerah, Dana Alokasi Umum, Dana Bagi Hasil, Dana Alokasi Khusus, Pendapatan Lain lain yang sah dan Penerimaan Pembiayaan berpengaruh signifikan positif terhadap realisasi belanja modal.
\end{abstract}




\section{Pendahuluan}

Peran Belanja modal bagi Pemerintah Daerah amat penting untuk kemajuan daerah tersebut, dengan belanja modal yang ada mampu meningkatkan kualitas layanan public dan mampu membuat iklim investasi menjadi baik yang pada akhirnya mampu menambah Pendapatan Asli Daerah tersebut. Daerah diharapkan menjadi mandiri dan mampu memenuhi kebutuhan anggaran di daerah tersebut.

Bengkulu identik dengan daerah yang kurang berkembang dan di buktikan dengan penurunan belanja modal dari tahun 20082010. Belanja modal Kab/Kota Bengkulu pada tahun 2008 sebesar Rp.1.561.023.669.627 dan pada tahun 2009 menurun menjadi Rp.1.350.116.595.552 dan pada tahun 2010 menurun menjadi Rp.1.018.465.669.111.

Faktor-faktor yang menyebabkan penurunan belanja modal bisa dipengaruhi oleh Pendapatan Asli Daerah, dana transfer yang terdiri dari Dana Bagi Hasil dan Dana Alokasi Khusus, Dana Alokasi Umum, pendapatan lainlain dan variabel Penerimaan pembiayaan.

Untuk faktor Pendapatan Asli Daerah terhadap belanja modal, hal ini berdasarkan review penelitian dari Solikin (2007) yang menunjukkan bahwa terdapat hubungan positif serta signifikan Pendapatan Asli Daerah terhadap belanja modal.

Untuk faktor Dana Alokasi Khusus terhadap belanja modal, hal ini berdasarkan review penelitian dari Situngkir (2009) yang menyatakan DAK berpengaruh positif terhadap belanja modal, serta penelitian dari Suratno (2015) yang menyatakan DAK berpengaruh positif terhadap pertumbuhan ekonomi, pertumbuhan ekonomi dimulai dari belanja modal. Untuk faktor pengaruh Dana Bagi Hasil terhadap belanja modal, hal ini berdasarkan review penelitian dari Sholikhah (2014) yang menyatakan DBH berpengaruh signifikan terhadap belanja modal. Untuk Pengaruh Dana Alokasi Umum terhadap belanja modal berlawanan dengan hasil Pengaruh Dana Alokasi Khusus dan Dana Bagi Hasil terhadap belanja modal. Berdasarkan review penelitian dari Sholikhah (2014) memperoleh hasil bahwa Dana Alokasi Umum tidak berpengaruh signifikan terhadap belanja modal.

Untuk faktor pengaruh pendapatan lain lain terhadap belanja modal, hal ini berdasarkan review dari penelitian dari Justin Lin \& Liu (2000) membuktikan adanya hubungan positif dan signifikan antara Pendapatan lain lain dengan Pertumbuhan Ekonomi, serta penelitian dari Suratno (2015) yang membuktikan bahwa dana otonomi khusus berpengaruh terhadap pertumbuhan ekonomi. Pertumbuhan Ekonomi dimulai dari Belanja Modal di Pemerintah daerah

Untuk faktor pengaruh penerimaan pembiayaan terhadap belanja modal Dan berdasarkan review penelitian sebelumnya dari Siswantoro (2012) yang meneliti Kabupaten/ Kota di Jawa Tengah memberikan hasil bahwa SiLPA berpengaruh positif dengan belanja modal. Dan review penelitian dari Ardhini (2011) memberikan hasil bahwa SiLPA berpengaruh positif dengan belanja modal, dan SiLPA merupakan bagian dari penerimaan pembiayaan.

Agar Bengkulu menjadi berkembang perlu berupaya untuk meningkatkan kualitas layanan publik dan pemerintah daerah wajib mengalokasikan dana dalam bentuk anggaran belanja modal dalam APBD. Alokasi belanja modal ini didasarkan pada kebutuhan daerah akan sarana dan prasarana, baik untuk kelancaran pelaksanaan tugas pemerintahan, investasi maupun fasilitas publik. Diharapkan dengan baiknya fasilitas publik di Provinsi Bengkulu, maka investor menjadi tertarik menanamkan modalnya di tempat tsb. Saragih (2003) menyatakan bahwa pemanfaatan belanja hendaknya di alokasikan untuk hal hal produktif, misalnya untuk melakukan aktivitas pembangunan, dan Stine (1994) menyatakan bahwa penerimaan pemerintah hendaknya lebih banyak untuk program program layanan publik. 
Penelitian ini dilakukan untuk menguji secara parsial dan simultan seberapa besar pengaruh PAD, Dana Perimbangan yang terdiri dari Dana Alokasi Umum, Dana Alokasi Khusus, Dana Bagi Hasil, dan Pendapatan lain lain yang sah serta Penerimaan Pembiayaan terhadap realisasi belanja modal.

\section{Telaah Teori dan Pengembangan Hipotesis}

\section{Pengertian Pendapatan Asli Daerah}

Pendapatan Asli Daerah (PAD) menurut Undang Undang RI Nomor 33 tahun 2004 tentang perimbangan keuangan antara pemerintah pusat dan pemerintah daerah adalah penerimaan yang diperoleh daerah dari sumber sumber di dalam daerahnya sendiri yang dipungut berdasarkan peraturan daerah sesuai dengan peraturan perundang undangan yang berlaku. Menurut Permendagri No.13 tahun 2006 tentang Pedoman Pengelolaan Keuangan Daerah arti Pendapatan Asli Daerah atau PAD merupakan semua penerimaan daerah yang berasal dari potensi sumber daya yang ada di daerah. Sumber-sumber PAD meliputi hasil pajak daerah, hasil retribusi daerah, hasil perusahaan milik daerah dan hasil pengelolaan kekayaan daerah lainnya yang dipisahkan, lain-lain pendapatan asli daerah yang sah. Simanjuntak (2003) menyatakan pajak daerah adalah pajak yang dipungut oleh daerah, seperti provinsi, kabupaten, maupun kotamadya berdasarkan peraturan daerah masingmasing dan hasil pemungutannya digunakan untuk pembiayaan rumah tangga daerahnya. Sedangkan Redjo (1998) berpendapat bahwa retribusi ialah suatu pembayaran dari rakyat kepada pemerintah dimana kita dapat melihat adanya hubungan antara balas jasa yang diterima langsung dengan adanya pembayaran retribusi tersebut, misalnya uang langganan air minum, uang langganan listrik.

\section{Pengertian Dana Perimbangan}

Menurut PP Nomor 55 tahun 2005tentang Dana Perimbangan, arti dana perimbangan adalah dana yang bersumber dari pendapatan APBN yang dialokasikan kepada daerah untuk mendanai kebutuhan daerah dalam rangka desentralisasi. Dana Perimbangan Menurut PP Nomor 55 tahun 2005 terdiri dari Dana Alokasi Umum, Dana Alokasi Khusus dan Dana Bagi Hasil.

Menurut PP Nomor 55 tahun 2005 mengenai dana perimbangan, arti Dana Alokasi Khusus, selanjutnya disebut DAK, adalah dana yang bersumber dari pendapatan APBN yang dialokasikan kepada daerah tertentu dengan tujuan untuk membantu mendanai kegiatan khusus yang merupakan urusan daerah dan sesuai dengan prioritas nasional, khususnya dalam upaya pemenuhan kebutuhan sarana dan prasarana pelayanan dasar masyarakat. DAK tidak dapat digunakan untuk mendanai administrasi kegiatan, penelitian, pelatihan, dan perjalanan dinas. Dana alokasi umum (DAU) adalah dana perimbangan dalam rangka untuk pemerataan kemampuan keuangan antar daerah (Bastian, 2003). Menurut PP Nomor 55 tahun 2005 tentang dana perimbangan arti Dana Alokasi Umum adalah dana yang bersumber dari pendapatan APBN yang dialokasikan dengan tujuan pemerataan kemampuan keuangan antar daerah untuk mendanai kebutuhan daerah dalam rangka pelaksanaan desentralisasi. Cara perhitungan Dana Alokasi Umum menurut PP no.55 tahun 2005 dialokasikan berdasarkan formula yang terdiri atas celah fiskal dan alokasi dasar. Celah fiskal sebagaimana dimaksud merupakan selisih antara kebutuhan fiskal dan kapasitas fiscal dan Alokasi dasar sebagaimana dimaksud dihitung berdasarkan jumlah gaji Pegawai Negeri Sipil Daerah. Menurut UU no.33 tahun 2004 tentang perimbangan keuangan Negara antara Pemerintah Pusat dan Pemerintah Daerah, adalah Dana bagi hasil bersumber dari pendapatan APBN yang di alokasikan kepada daerah dengan angka persentase tertentu didasarkan atas daerah penghasil untuk mendanai kebutuhan daerah dalam rangka pelaksanaan desentralisasi. 


\section{Pengertian Pendapatan lain lain}

Dana transfer lainnya atau pendapatan lain lain menurut permendagri 13 tahun 2006 tentang Pedoman Pengelolaan Keuangan Daerah terdiri atas Dana Hibah, Dana Penyesuaian, Dana otonomi khusus. Dana darurat dan Bantuan keuangan ke pemerintah daerah lainnya. Dana penyesuaian adalah dana yang dialokasikan untuk membantu daerah dalam rangka melaksanakan kebijakan tertentu sesuai peraturan perundangan yang terdiri atas dana insentif daerah, Dana Tambahan Penghasilan Guru Pegawai Negeri Sipil Daerah (PNSD), Dana Bos (Bantuan Operasional Sekolah).

\section{Pengertian Penerimaan Pembiayaan}

Menurut Permendagri Nomor 13 tahun 2006 tentang Pedoman Pengelolaan Keuangan Daerah pasal 60, Penerimaan Pembiayaan terdiri dari sisa lebih perhitungan anggaran tahun anggaran sebelumnya (SiLPA), pencairan dana cadangan, hasil penjualan kekayaan daerah yang dipisahkan, Penerimaan pinjaman daerah, dan penerimaan piutang daerah. Menurut Permendagri Nomor 52 tahun 2015 tentang Pedoman Penyusunan Anggaran Pendapatan dan Belanja Daerah Tahun Anggaran 2016, SiLPA atas sisa penerimaan dana alokasi khusus yang tidak terpakai tahun sebelumnya bisa digunakan untuk kegiatan fisik untuk tahun berikutnya dan menurut Permendagri Nomor 13 Tahun 2006 tentang pedoman pengelolaan keuangan daerah bahwa pencairan dana cadangan digunakan untuk pembangunan daerah sesuai yang ditetapkan Perda dan penerimaan piutang daerah bisa digunakan untuk belanja daerah .

\section{Pengaruh Pendapatan Asli Daerah terhadap realisasi belanja modal}

PAD merupakan salah satu sumber dana untuk belanja daaerah, jika PAD meningkat maka dana yang dimiliki pemerintah daerah akan lebih tinggi dan tingkat kemandirian daerah akan meningkat pula, sehingga pemerintah daerah akan lebih berinisiatif untuk menggali potensi daerah dan meningkatkan pertumbuhan ekonomi (Tambuhan, 2006), semakin besar PAD, maka dana yang terakumulasi semakin banyak dan mampu membiayai belanja daerah, artinya semakin besar Pendapatan Asli daerah maka semakin besar alokasi belanja modal yang di berikan dan didukung dengan review penelitian sebelumnya dari Solikin (2007) menunjukkan adanya pengaruh PAD terhadap belanja modal. Berdasarkan paparan tersebut, dirumuskan hipotesis sebagai berikut,

Hipotesis 1 (H1): Pendapatan Asli Daerah berpengaruh signifikan terhadap realisasi belanja modal.

\section{Pengaruh Dana Perimbangan terhadap realisasi belanja modal}

Menurut PP Nomor. 55 tahun 2005 mengenai dana perimbangan, arti Dana Alokasi Khusus adalah dana yang bersumber dari pendapatan APBN yang dialokasikan kepada daerah tertentu dengan tujuan untuk membantu mendanai kegiatan khusus yang merupakan urusan daerah dan sesuai dengan prioritas nasional, khususnya dalam upaya pemenuhan kebutuhan sarana dan prasarana pelayanan dasar masyarakat. DAK tidak dapat digunakan untuk mendanai administrasi kegiatan, penelitian, pelatihan, dan perjalanan dinas. Berdasarkan hal tersebut maka dana alokasi khusus berpengaruh signifikan terhadap realisasi belanja modal dan di dukung dengan review dari penelitian sebelumnya dari Situngkir (2009), yang dana alokasi khusus berpengaruh signifikan terhadap belanja modal. Dana alokasi umum (DAU) adalah dana perimbangan dalam rangka untuk pemerataan kemampuan keuangan antar daerah (Bastian, 2003). Dan cara perhitungan Dana Alokasi Umum menurut PP Nomor 55 tahun 2005 dialokasikan berdasarkan formula yang terdiri atas celah fiskal dan alokasi dasar. Celah fiskal sebagaimana dimaksud merupakan selisih antara kebutuhan fiskal dan kapasitas fiscal dan Alokasi dasar sebagaimana dimaksud dihitung berdasarkan jumlah gaji pegawai negeri sipil 
daerah berdasarkan teori tersebut maka dana alokasi umum tidak berpengaruh terhadap belanja modal karena mayoritas dana alokasi umum banyak digunakan untuk membiayai gaji pegawai negri sipil, dan didukung dengan review sebelumnya yang di lakukan oleh Sholikhah (2014) yang memperoleh hasil bahwa Dana Alokasi Umum tidak berpengaruh terhadap belanja modal. Menurut UU Nomor 33 tahun 2004 tentang perimbangan keuangan negara antara Pemerintah Pusat dengan Pemerintah Daerah arti dana bagi hasil bersumber dari pendapatan APBN yang di alokasikan kepada daerah dengan angka persentase tertentu didasarkan atas daerah penghasil untuk mendanai kebutuhan daerah dalam rangka pelaksanaan desentralisasi, berjalannya system transfer dana bagi hasil mencerminkan adanya otonomi yang seluas luasnya dalam upaya meningkatkan pertumbuhan ekonomi daerah. Berdasarkan teori di atas maka dana bagi hasil berpengaruh signifikan terhadap belanja modal, hal ini didukung review penelitian dari Sholikhah (2014) yang menyatakan DBH berpengaruh signifikan terhadap belanja modal. Berdasarkan teori di atas maka dirumuskan hipotesis sebagai berikut,

Hipotesis 2 (H2): Dana perimbangan berpengaruh signifikan terhadap belanja modal.

\section{Pengaruh pendapatan lain lain yang sah terhadap realisasi belanja modal}

Dana Insentif Daerah digunakan untuk meningkatkan pertumbuhan ekonomi, pertumbuhan ekonomi di mulai dari belanja modal. Dan menurut petunjuk teknis penggunaan dana bantuan operasional sekolah digunakan untuk memperbaiki sarana dan prasarana sekolah seperti pembelian komputer, biaya perawatan gedung dan hibah bisa berubah hibah aktiva tetap berdasarkan teori tersebut maka pendapatan lain lain yang sah berpengaruh positif terhadap realisasi belanja modal dan di dukung dengan didukung review dari Lin \& Liu (2000) membuktikan adanya hubungan positif dan signifikan antara pendapatan lain lain dengan pertumbuhan ekonomi. Berdasarkan teori di atas maka dirumuskan hipotesis sebagai berikut, Hipotesis 3 (H3): Pendapatan Lain Lain berpengaruh signifikan terhadap belanja modal.

\section{Pengaruh Penerimaan Pembiayaan terhadap realisasi belanja modal}

Menurut Permendagri Nomor 52 tahun 2015 tentang Pedoman Penyusunan Anggaran Pendapatan dan Belanja Daerah Tahun Anggaran 2016, SiLPA atas sisa penerimaan dana alokasi khusus yang tidak terpakai tahun sebelumnya bisa digunakan untuk kegiatan fisik untuk tahun berikutnya dan pencairan dana cadangan dan penerimaan piutang daerah bisa digunakan untuk keperluan kegiatan fisik. Jadi semakin besarnya Penerimaan Pembiayaan artinya semakin banyak uang yang terkumpul dari SiLPA, dari pencairan dana cadangan, penerimaan pinjaman daerah dan dari penerimaan piutang daerah maka akan mampu membiayai belanja modal. Dan berdasarkan review penelitian sebelumnya dari di Jawa Tengah memberikan hasil bahwa SiLPA berpengaruh positif dengan belanja modal.

Berdasarkan teori di atas maka Berdasarkan teori di atas maka dirumuskan hipotesis sebagai berikut,

Hipotesis 4 (H4): Penerimaan Pembiayaan berpengaruh signifikan terhadap belanja modal

\section{Pengaruh PAD, Dana Perimbangan, Penda- patan lain lain dan Penerimaan Pembiayaan terhadap realisasi belanja modal}

Menurut Sidik (2002), ciri utama yang menunjukkan suatu daerah otonom mampu berotonomi terletak pada kemampuan keuangan daerah. Artinya, daerah otonom harus memiliki kewenangan dan kemampuan untuk menggali sumber - sumber keuangan sendiri, mengelola dan menggunakan keuangan sendiri yang cukup memadai untuk membiayai penyelenggaraan pemerintahan daerahnya. Dan review dari Sumarmi (2009) menyatakan bahwa secara simultan PAD, DAU, DAK, DBH, berpengaruh 
secara signifikan terhadap belanja modal. Berdasarkan teori diatas, dikembangkan hipotesis penelitian sebagai berikut,

Hipotesis 5 (H5): PAD, Dana Perimbangan, Pendapatan Lain-lain dan Penerimaan Pembiayaan secara simultan berpengaruh signifikan terhadap belanja modal.

\section{Metode Penelitian}

Populasi dalam penelitian ini adalah seluruh Kabupaten/kota di Bengkulu dari periode 20082013. Total Populasi sebesar 66, sedangkan sampel yang digunakan adalah berjumlah 10 kabupaten/kota di Bengkulu dari periode 20082013 sehingga total sampel sebesar 60. Metode pemilihan sample adalah purposive sample, karena sample yang di ambil memenuhi kriteria tertentu yaitu tidak rusak, lengkap, melaporkan Laporan Realisasi Anggaran secara konsisten dari tahun 2008 sampai tahun 2013 dan sudah diaudit oleh BPK. Teknik analisis data yang digunakan dalam penelitian ini adalah menggunakan uji asumsi klasik yang terdiri dari Uji Normalitas, Uji Autokorelasi, Uji Multikolinieritas dan Uji Heterokedasitas, Uji Determinasi, Uji Simultan (Uji F) dan Uji Parsial (Uji T) dan regresi linier.

Jenis data yang digunakan adalah data kuantitatif. Dalam penelitian ini menggunakan data sekunder. Data sekunder berupa laporan realisasi anggaran Pemda Kabupaten/Kota Bengkulu yakni data PAD, DAK, DAU, DBH, Pendapatan Lain-Lain dan Penerimaan Pembiayaan yang diperoleh melalui situs www. djpk.kemenkeu.go.id dari tahun 2008 sampai tahun 2013.Variabel dependen adalah Realisasi Belanja modal, dan variabel independen adalah Pendapatan asli daerah, dana perimbangan yang terdiri dari DAU, DAK, DBH, Pendapatan Lain lain yang sah dan Penerimaan Pembiayaan.

Berdasarkan Metode Analisis data maka persamaan regresinya dapat ditulis sebagai berikut:

$$
\mathrm{Y}=\alpha+\beta_{1} \mathrm{X}_{1}+\beta_{2} \mathrm{X}_{2}+\beta_{3} \mathrm{X}_{3}+\beta_{4} \mathrm{X}_{4}+\mathrm{e}
$$

$$
\begin{aligned}
\mathrm{Y}= & \text { Belanja modal } \\
\alpha= & \text { Konstanta } \\
\mathrm{X}_{1}= & \text { PAD (Pendapatan Asli Daerah) } \\
\mathrm{X}_{2}= & \text { Dana Perimbangan yang terdiri dari } \\
& \text { Dana Alokasi Umum, Dana Alokasi } \\
& \text { Khusus dan Dana Bagi Hasil } \\
\mathrm{X}_{3}= & \text { Pendapatan lainlain } \\
\mathrm{X}_{4}= & \text { Penerimaan pembiayaan } \\
\mathrm{e}^{=} & \text {Variable pengganggu }
\end{aligned}
$$

\section{Hasil Penelitian Dan Pembahasan}

Hasil uji Normalitas yang baik seharusnya data berdistribusi normal, salah satu cara mendeteksi data berdistribusi normal adalah dengan uji Statistic Kolmogorov Smirnov, jika Asymp. Sig. (2-tailed) di atas 0,05 maka data berdistribusi normal. Hasil hitung uji Statistic Kolmogorov Smirnov Asymp. Sig. (2-tailed) bernilai 0,71 artinya data berdistribusi normal.

Hasil Uji Multikolinieritas yang baik seharusnya tidak terjadi korelasi diantara variabel independen atau bebas dari Multikolinieritas. Hasil perhitungan tolerance menunjukkan tidak ada variabel independen yang memiliki tolerance kurang dari 0,10 dan hasil perhitungan nilai VIF juga menunjukkan tidak ada satu variabel independen yang memiliki nilai VIF lebih dari 10. Jadi dapat disimpulkan bahwa tidak terdapat multikolinieritas antar variabel independen dalam model regresi. Hasil Uji Autokorelasi nilai Durbin Watson sebesar 1.977 sementara batas DU adalah sebesar 1.808, maka dapat di simpulkan bahwa hasilnya adalah $\mathrm{DU}<\mathrm{D}<4$ DU dan hasilnya Tidak ada Autokorelasi positif atau negative. Sehingga dapat disimpulkan variabel tidak terdapat autokorelasi. Hasil Uji Heterokedastisitas adalah dari tabel Sig. (2-tailed) Unstandardized Residual lebih dari 0,05 , maka tidak terjadi heterokedasitas.

Hasil perhitungan koefisien determinasi yang dilihat dari nilai adjusted $\mathrm{R}$ square sebesar 0,859 hal ini berarti $85,9 \%$ realisasi belanja modal dapat dijelaskan oleh variasi dari ke enam variabel independen yaitu Pendapatan 
Asli Daerah, Dana Alokasi Umum, Dana Alokasi Khusus, Dana Bagi Hasil, Pendapatan lain lain yang sah dan Penerimaan Pembiayaan. Sedangkan sisanya $\quad(100 \%-85,9 \%=14,1 \%)$ dijelaskan oleh sebab yang lain diluar model.

\section{Pengujian Regresi}

Pada Pengujian regresi dapat dilihat hasil pengolahan data SPSS yang menghasilkan output pada tabel 1 adalah sebagai berikut.

Tabel 1. Persamaan Regresi dan Uji T

\begin{tabular}{llllll}
\hline Variabel & \multicolumn{1}{c}{ B } & $\begin{array}{c}\text { Std. } \\
\text { Error }\end{array}$ & $\begin{array}{c}\text { Std. } \\
\text { Beta }\end{array}$ & t & Sig. \\
\hline (Constant) & 80923975 & 1.71322 & & 4.725 & 0 \\
PAD & 0.328 & 0.055 & 0.663 & 5.978 & 0.000 \\
DAU & -0.155 & 0.044 & -0.368 & -3.53 & 0.001 \\
DAK & 0.9 & 0.283 & 0.225 & 3.178 & 0.002 \\
DBH & 0.079 & 0.082 & 0.063 & 0.960 & 0.342 \\
PLS & 0.239 & 0.087 & 0.188 & 2.742 & 0.008 \\
PP & 0.49 & 0.061 & 0.576 & 8.008 & 0.000 \\
\hline
\end{tabular}

Sumber : Data diolah

Berdasarkan Tabel 1 di atas, maka dapat diperoleh persamaan regresi sebagai berikut:

$\mathrm{Y}=80.923 .975+0.328 \mathrm{X}_{1}-0.155 \mathrm{X}_{2}+0.9 \mathrm{X}_{3}+0.079 \mathrm{X}_{4}+0.239 \mathrm{X}_{5}+0.49 \mathrm{X}_{6}+\mathrm{e}$

Keterangan:

$\mathrm{X}_{1}=$ Pendapatan Asli Daerah,

$\mathrm{X}_{2}=$ Dana Alokasi Umum,

$\mathrm{X}_{3}=$ Dana Alokasi Khusus,

$\mathrm{X}_{4}=$ Dana Bagi Hasil,

$\mathrm{X}_{5}=$ Pendapatan Lain Lain yang Sah,

$\mathrm{X}_{6}=$ Penerimaan Pembiayaan

\section{Uji Parsial (Uji t)}

Uji statistic $t$ dilakukan untuk setiap variabel bebas apakah mempunyai pengaruh yang signifikan terhadap variabel terikat secara parsial.

Berdasarkan hasil perhitungan uji t pada tabel 1 maka dapat disimpulkan sebagai berikut:

1. Variabel Pendapatan Asli Daerah memiliki

$\mathrm{t}$ hitung sebesar 5,978 lebih besar dari $\mathrm{t}$ tabel sebesar 1,671 dengan nilai sigifikansi sebesar 0 atau lebih kecil dari 0,05, artinya bahwa PAD berpengaruh signifikan terhadap realisasi belanja modal.

2. Variabel Dana Alokasi Umum memiliki $t$ hitung sebesar $-3,53$ lebih besar negative dari $\mathrm{t}$ tabel sebesar 1,671 dengan nilai sigifikansi sebesar 0,001 atau lebih kecil dari 0,05 , artinya bahwa DAU berpengaruh negative terhadap realisasi belanja modal.

3. Variabel Dana Alokasi Khusus memiliki $\mathrm{t}$ hitung sebesar 3,178 lebih besar dari $\mathrm{t}$ tabel sebesar 1,671 dengan nilai sigifikansi sebesar 0,002 atau lebih kecil dari 0,05, artinya bahwa DAK berpengaruh signifikan terhadap realisasi belanja modal.

4. Variabel Dana Bagi Hasil memiliki t hitung sebesar 0,96 lebih kecil dari t tabel sebesar 1,671 dengan nilai sigifikansi sebesar 0,342 atau lebih besar dari 0,05, artinya bahwa DBH tidak berpengaruh terhadap realisasi belanja modal. Hal ini menunjukkan bahwa besaran dana realisasi belanja modal tidak dapat ditentukan dari DBH.

5. Variabel Pendapatan Lain Lain yang sah memiliki t hitung sebesar 2,742 lebih besar dari $t$ tabel sebesar 1,671 dengan 
nilai sigifikansi sebesar 0,008 atau lebih kecil dari 0,05 , artinya bahwa Pendapatan lain lain yang sah berpengaruh signifikan terhadap realisasi belanja modal.

6. Variabel Penerimaan Pembiayaan memiliki t hitung sebesar 8,008 lebih besar dari t tabel sebesar 1,671 dengan nilai sigifikansi sebesar 0 atau lebih kecil dari 0,05, artinya bahwa Penerimaan Pembiayaan berpengaruh signifikan terhadap realisasi belanja modal.

\section{Uji Simultan (Uji F)}

Uji F Statistik dilakukan untuk melihat secara bersama sama (Simultan) apakah ada pengaruh signifikan variabel bebas terhadap variabel terikat (Realisasi Belanja Modal).

Hasil F hitung sebesar 60.748 lebih besar dari $F$ tabel sebesar 2,25 serta nilai signifikansi sebesar 0,000 atau lebih kecil dari 0,05 . Sehingga hipotesis alternative enam (Ha5) diterima artinya bahwa "Pendapatan Asli Daerah (PAD), Dana Alokasi Umum (DAU), Dana Alokasi Khusus (DAK), Dana Bagi Hasil (DBH), Pendapatan Lain lain yang sah dan Penerimaan Pembiayaan berpengaruh secara simultan terhadap realisasi Belanja Modal.

\section{Pengaruh Pendapatan Asli Daerah terhadap realisasi belanja modal}

Hasil penelitian ini menyatakan bahwa Pendapatan Asli Daerah berpengaruh signifikan terhadap realisasi belanja modal. Belanja modal dapat dibiayai dari penerimaan daerah. Penerimaan daerah diantaranya adalah Pendapatan Asli Daerah, sehingga dapat disimpulkan bahwa semakin besar Pendapatan Asli Daerah maka semakin besar dana yang dialokasikan pada realisasi Belanja Modal. Hal ini konsisten dengan hasil penelitian sebelumnya yang dilakukan Suasanti (2016), Nur'aeni dan Suratno (2015). Handayani dan Nuraeni (2014), Situngkir (2009), Solikin (2007) yang meneliti di Jawa Barat yang mendapatkan hasil bahwa PAD berpengaruh positif terhadap belanja modal.
Hasil penelitian tidak mendukung penelitian Abdullah dan Rona (2014)

\section{Pengaruh Dana Perimbangan terhadap realisasi belanja modal}

Dari hasil penelitian menyatakan bahwa Dana Alokasi Umum berpengaruh negative terhadap kenaikan realisasi belanja modal, yang artinya bahwa semakin besar dana alokasi umum berarti semakin kecil dana yang digunakan untuk realisasi belanja modal, dikarenakan dana alokasi umum banyak digunakan untuk belanja pegawai, hal ini sesuai dengan Peraturan Pemerintah Nomor 55 tahun 2005 tentang Dana Perimbangan bahwa perhitungan Dana Alokasi Umum di dapat dari Alokasi Dasar ditambah Celah Fiskal, dimana arti Alokasi Dasar adalah Belanja Pegawai negeri Sipil Daerah.

Dari hasil penelitian menyatakan bahwa Dana Bagi Hasil tidak berpengaruh signifikan terhadap kenaikan realisasi belanja modal, yang artinya bahwa semakin besar atau kecil Dana Bagi Hasil berarti tidak berpengaruh terhadap besar dana yang digunakan untuk realisasi belanja modal. DBH tidak berpengaruh terhadap realisasi belanja modal dikarenakan Pendapatan Dana Bagi Hasil banyak yang tidak terpakai dan menjadi SiLPA, penyebab SilPA bermacam macam adayang disebabkan oleh ketidakberanian Pemerintah Daerah dalam menggunakan anggarannya karena tidak jelasnya peraturan mengenai jenis penggunaan atau karena tidak adanya kebutuhan yang menggunakan dana dari sumber Dana Bagi Hasil. Hal ini bertentangan dengan hasil penelitian Andriani dan Yuliana (2016), Sholikhah dan Wahyudin (2014) yang meneliti di pulau Jawa yang menyatakan bahwa DBH berpengaruh significant terhadap realisasi belanja modal.

Hasil penelitian ini menyatakan bahwa Dana Alokasi Khusus berpengaruh signifikan terhadap realisasi belanja modal, artinya bahwa semakin besar Dana Alokasi Khusus maka semakin besar realisasi belanja modal. Hal ini sesuai dengan teori Peraturan Pemerintah Nomor 
55 Tahun 2005 tentang Dana Perimbangan dimana dana DAK digunakan untuk membantu mendanai kegiatan khusus yang merupakan urusan daerah dan sesuai dengan prioritas nasional, khususnya dalam upaya pemenuhan kebutuhan sarana dan prasarana pelayanan dasar masyarakat. DAK tidak dapat digunakan untuk mendanai administrasi kegiatan, penelitian, pelatihan, dan perjalanan dinas. Hal ini konsisten dengan penelitian sebelumnya yang dilakukan oleh Sianipar (2011) yang menyatakan DAK berpengaruh positif dan signifikan terhadap belanja modal.

\section{Pengaruh Pendapatan lain lain yang sah terhadap realisasi belanja modal}

Hasil penelitian ini menyatakan bahwa Pendapatan lain lain yang sah berpengaruh signifikan terhadap realisasi belanja modal, artinya bahwa semakin besar Pendapatan lain lain yang sah maka semakin besar realisasi belanja modal. Hasil penelitian mendukung penelitian Andriani dan Yuliana (2016), Susanti dan Fahlevi (2016), Sugiarti dan Supadmi (2014).

\section{Pengaruh Penerimaan Pembiayaan terhadap realisasi belanja modal}

Hasil penelitian ini menyatakan bahwa Penerimaan Pembiayaan berpengaruh signifikan terhadap belanja modal, artinya semakin besar uang yang terkumpul dari SiLPA, dari pencairan dana cadangan, pinjaman daerah, dari penerimaan piutang daerah maka semakin besar realisasi belanja modal. Menurut Permendagri Nomor 52 tahun 2015 tentang Pedoman Penyusunan Anggaran Pendapatan dan Belanja Daerah Tahun Anggaran 2016, SiLPA atas sisa penerimaan dana alokasi khusus yang tidak terpakai tahun sebelumnya bisa digunakan untuk kegiatan fisik untuk tahun berikutnya dan menurut Permendagri Nomor 13 Tahun 2006 tentang pedoman pengelolaan keuangan daerah bahwa pencairan dana cadangan digunakan untuk pembangunan daerah sesuai yang ditetapkan Perda. Penelitian ini mendukung penelitian Andriani dan Yuliana (2016),

\section{Kesimpulan, Keterbatasan dan Implikasi Hasil Penelitian}

Penelitian ini bertujuan untuk mengetahui dan menganalisis bukti empiris pengaruh dari Pendapatan Asli Daerah, Dana Perimbangan yang terdiri dari Dana Alokasi Umum, Dana Alokasi Khusus dan Dana Bagi Hasil, Pendapatan lain lain yang sah dan pengeluaran pembiayaan terhadap realisasi belanja modal. Berdasarkan hasil pengujian yang telah dilakukan, dapat diperoleh kesimpulan bahwa secara Parsial Variabel Pendapatan Asli Daerah berpengaruh positif terhadap realisasi belanja modal.Hal ini menunjukkan bahwa besaran dana realisasi belanja modal dapat ditentukan dari PAD. Untuk rincian dana perimbangan secara parsial variabel Dana Alokasi Umum berpengaruh negative terhadap realisasi belanja modal, secara parsial variabel Dana Alokasi Khusus berpengaruh positif terhadap realisasi belanja modal, Hal ini menunjukkan bahwa besaran dana realisasi belanja modal dapat ditentukan dari DAK, dan secara parsial variabel Dana Bagi Hasil tidak berpengaruh terhadap realisasi belanja modal. Hal ini menunjukkan bahwa besaran dana realisasi belanja modal tidak dapat ditentukan dari DBH. Untuk Hasil

Variabel Pendapatan Lain Lain yang sah berpengaruh positif terhadap realisasi belanja modal. Hal ini menunjukkan bahwa besaran dana realisasi belanja modal dapat ditentukan dari Pendapatan lain lain yang Sah. Untuk Hasil variabel Penerimaan Pembiayaan secara Parsial variabel Penerimaan Pembiayaan berpengaruh positif terhadap realisasi belanja modal. Hal ini menunjukkan bahwa besaran dana realisasi belanja modal dapat ditentukan dari Penerimaan Pembiayaan. Secara Simultan Pendapatan Asli Daerah (PAD), Dana Alokasi Umum (DAU), Dana Alokasi Khusus (DAK), Dana Bagi Hasil 
(DBH), Pendapatan Lain lain yang sah dan Penerimaan Pembiayaan berpengaruh secara simultan terhadap realisasi Belanja Modal.

Keterbatasan penelitian itu yaitu sampel penelitian ini hanya 10 kabupaten/kota di Bengkulu yang memenuhi kriteria, sehingga belum dapat digeneralisasi untuk seluruh kabupaten/kota di Indonesia, Penelitian ini tidak membahas kebijakan Pemerintah Daerah dalam penentuan realisasi belanja modal dan penelitian ini hanya meneliti selama 6 tahun dari 20082013 akan lebih baik jika meneliti lebih dari 6 tahun agar hasil bisa lebih akurat. Akibat dari keterbatasan tersebut adalah

Setelah penelitian ini diharapkan pada pihak manajemen Pemda Bengkulu untuk meningkatkan realisasi belanja modal dengan upaya mengoptimalkan pemberdayaan sumberdaya yang dimiliki seperti memanfaatkan Dana Alokasi Khusus, Dana Bagi hasil dan Penerimaan pembiayaan untuk dapat membiayai pembangunan di daerah tersebut yang berfungsi sebagai peningkatan pelayanan public dan fungsi investasi. Dana Alokasi Umum tidak berpengaruh terhadap realiasasi belanja modal karena DAU banyak di alokasikan untuk gaji dan honorarium PNSD, maka untuk selanjutnya Dana Alokasi Umum sebaiknya tidak semuanya untuk honorarium PNSD namun digunakan untuk belanja modal baik berupa pelayanan public maupun belanja modal untuk meningkatkan PAD di daerah tersebut. Dan untuk Dana Bagi Hasil tidak berpengaruh terhadap hasil penelitian karena selain bukti berdasarkan statistic SPSS juga di karenakan pendapatan Dana Bagi Hasil banyak yang tidak terpakai dan menjadi SilPA, penyebab SilPA bermacam - macam ada yang di sebabkan oleh ketidak beranian Pemerintah Daerah dalam menggunakan anggarannya karena tidak jelasnya peraturan mengenai jenis penggunaan atau di karenakan tidak ada kebutuhan untuk belanja modal yang menggunakan dana dari sumber Dana Bagi Hasil.

\section{Daftar Referensi}

Abdullah, S., \& Rona, R. (2014). Pengaruh Sisa Anggaran, Pendapatan Sendiri dan Dana Perimbangan terhadap Belanja Modal. IQTISHADIA (Journal of Islamic Economics and Business), 7(1), 179-202.

Andriani, N. L. P. O., \& Yuliana, L. (2016). Analisis Determinan Belanja Modal Pemerintah Provinsi di Indonesia Tahun 2010-2013. Jurnal Ilmiah Widya, 1(1).

Bastian, Indra. 2003 Akuntansi Sektor Publik di Indonesia. Universitas Gajah Mada, Yogyakarta.

Handayani, D., \& Nuraina, E. (2012). Pengaruh Pajak Daerah dan Dana Alokasi Khusus Terhadap Alokasi Belanja Daerah Kabupaten Madiun. Assets: Jurnal Akuntansi dan Pendidikan, 1(1), 1-12.

Kosim, E. (2017). Pengaruh Pendapatan Asli Daerah (PAD), Dana Alokasi Umum (DAU) dan Sisa Lebih Pembiayaan Anggaran (Silpa) Terhadap Anggaran Belanja Modal Pada Pemerintah Kota Banjar. Journal of Management Review, 1(1), 12-22.

Lin, J. Y., \& Liu, Z. (2000). Fiscal decentralization and economic growth in China. Economic development and cultural change, 49(1), $1-21$.

Nur'aeni, Y., \& Suratno, S. (2015). Pengaruh PAD, DAU, DAK dan DOK terhadap Produk Domestik Regional Bruto. JRAP (Jurnal Riset Akuntansi dan Perpajakan), 2(1).

Peraturan Pemerintah Nomor 55 Tahun 2005 tentang Dana Perimbangan.

Peraturan Pemerintah Republik Indonesia Nomor. 71 tahun 2010 Tentang Standar Akuntansi Pemerintahan.

Permendagri Nomor 13 tahun 2006 Tentang Pedoman Pengelolaan Keuangan Daerah.

Redjo, Samagio Ibnu. 1998. Keuangan Pusat dan Daerah. BKU Ilmu Pemerintahan Fakultas Ekonomi Pascasarjana Kerjasama Universitas Padjajaran. Bandung. 
Saragih, Juli Panglima. 2003. Desentralisasi Fiskal dan Keuangan Daerah dalam Otonomi. Cetakan Pertama. Penerbit Ghalia Indonesia. Jakarta.

Sholikhah, I., \& Wahyudin, A. (2014). Analisis Belanja Modal Pada Pemerintah Kabupaten/Kota Di Jawa. Accounting Analysis Journal, 3(4).

Sidik. Machfud. 2002. Optimalisasi Pajak Daerah dan Retribusi Daerah dalam Rangka Meningkatkan Kemampuan Daerah.

Situngkir, A. (2009). Pengaruh Pertumbuhan Ekonomi, Pendapatan Asli Daerah, Dana Alokasi Umum Dan Dana Alokasi Khusus Terhadap Anggaran Belanja Modal Pada Pemko/Pemkab Sumatera Utara (Masterss thesis)..

Solikin, I. (2007). Hubungan pendapatan asli daerah dan dana alokasi umum dengan belanja modal di Jawa Barat. Online,, Jurnal PAD, 1-13
Stine, W. F. (1994). Is local government revenue response to federal aid symmetrical? Evidence from Pennsylvania county governments in an era of retrenchment. National Tax Journal, 799816.

Sugiarthi, N. P. D. E. R., \& Supadmi, N. L. (2014). Pengaruh PAD, DAU, dan SILPA pada Belanja Modal dengan Pertumbuhan Ekonomi sebagai Pemoderasi. E-Jurnal Akuntansi.

Susanti, S., \& Fahlevi, H. (2016). Pengaruh Pendapatan Asli Daerah, Dana Alokasi Umum, dan Dana Bagi Hasil terhadap Belanja Modal (Studi pada Kabupaten/Kota di Wilayah Aceh). Jurnal Ilmiah Mahasiswa Ekonomi Akuntansi, 1(1), 183-191.

Undang-Undang No. 33 Tahun 2004 Tentang perimbangan keuangan antara pemerintah pusat dan pemerintah daerah. 